\title{
Mapeamento Geomorfológico da Porção Nordeste da Ilha do Cardoso (SP) nos Anos 2013 e 2018 Como Subsídio Para Discussão da Dinâmica Terra-mar.
}

\section{Flávia Correr Stenico*, Regina Célia de Oliveira, Pedro Michelutti Cheliz.}

\section{Resumo}

O mapeamento geomorfológico da porção nordeste da llha do Cardoso em dois cenários (2013 e 2018) subsidiou a análise e a discussão dos processos morfodinâmicos atuantes que promovem intensas transformações na área.

\section{Palavras-chave:}

Ilha do Cardoso, dinâmica costeira, mapeamento geomorfológico.

\section{Introdução}

A Ilha do Cardoso (SP), especialmente na porção nordeste, se configura como uma área de intensas dinâmicas geomorfológicas costeiras. Desta forma, o presente projeto buscou analisar esses processos através da elaboração de mapeamentos de compartimentação geomorfológica de detalhe (escala 1:25000), dialogando com a metodologia de Tricart (1965) e trabalhos anteriores efetuados na totalidade da Ilha (Cheliz, 2015) Estes mapas fornecem subsídios para uma discussão e uma análise acerca dos processos e das dinâmicas atuantes na llha, resultando em um estudo comparativo sobre as alterações da geomorfologia litorânea do setor nordeste.

\section{Resultados e Discussão}

Os mapas geomorfológicos da porção nordeste da llha do Cardoso (SP) são referentes aos anos de 2013 e de 2018 e foram elaborados em diálogo com a metodologia de Tricart (1965) e com os critérios de compartimentação geomorfológica estabelecidos por Cheliz (2015). Esses produtos cartográficos permitem uma análise acerca das mudanças que ocorreram no intervalo de cinco anos nesta porção da llha.

Figuras 1 e 2. Mapas da Compartimentação Geomorfológica da porção nordeste da llha do Cardoso (SP), dos anos de 2013 e 2018, respectivamente. Fonte: Autoria própria.
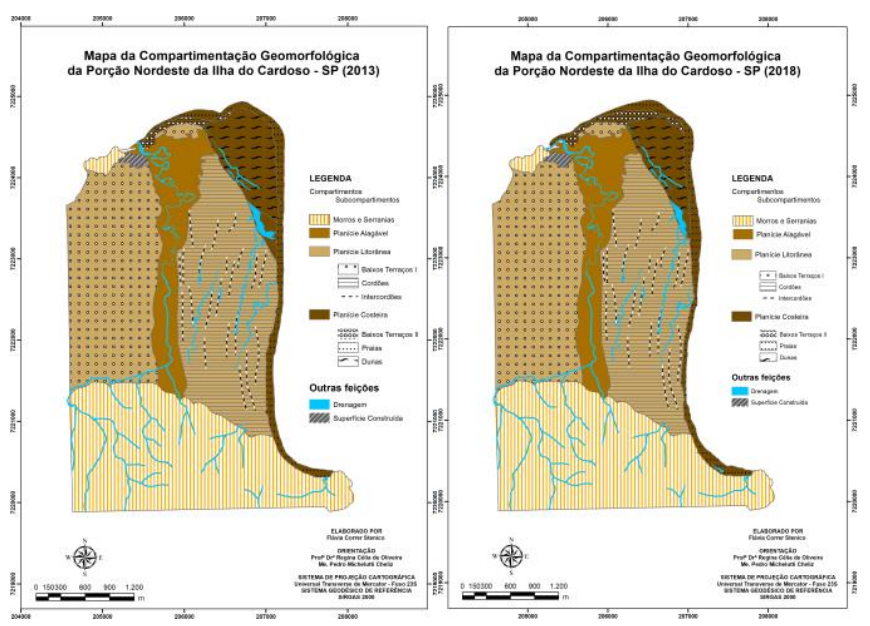

Os compartimentos e subcompartimentos presentes no segmento nordeste da llha são afetados de maneiras distintas pela ação eólica, pelas águas oceânicas e fluviais e pelas oscilações de maré, promovendo assim a diferenciação das formas de relevo e a intensa transformação da paisagem.

Tabelas 1 e 2. Áreas totais dos compartimentos e subcompartimentos, em $\mathrm{Km}^{2}$, dos anos de 2013 e 2018. Fonte: Autoria própria.

\begin{tabular}{|c|c|c|}
\hline Compartimentos & Área Total $2013\left(\mathrm{Km}^{2}\right)$ & Área Total $2018\left(\mathrm{Km}^{2}\right)$ \\
\hline Planície Alagável & 1,23 & 1,25 \\
\hline Planicie Litorānea & 5,98 & 5,83 \\
\hline Planície Costeira & 1,43 & 1,25 \\
\hline Morros e Serranias & 3,85 & 3,82 \\
\hline Superficie Construída & 0,04 & 0,04 \\
\hline Subcompartimentos & Área Total $2013\left(\mathrm{~km}^{2}\right)$ & Área Total $2018\left(\mathrm{Km}^{2}\right)$ \\
\hline Baixos Terraços I & 2,85 & 2,85 \\
\hline Baixos Terraços II & 0,07 & 0,13 \\
\hline Cordőes Litorâneos & 3,05 & 2,88 \\
\hline
\end{tabular}

As tabelas acima demonstram as variações das áreas dos compartimentos e subcompartimentos nos dois anos analisados, corroborando assim a análise acerca das modificações na geomorfologia da Ilha.

\section{Conclusões}

Os traços e as formas de relevo da Ilha do Cardoso estão em constante remobilização e reconfiguração em virtude das oscilantes condições morfodinâmicas, promovendo assim, em um relativo curto espaço de tempo, alterações pronunciadas nos compartimentos e subcompartimentos, isto é, na geomorfologia da llha como um todo.

\section{Agradecimentos}

Agradeço ao CNPq pela oportunidade de desenvolver esta pesquisa; à Prof ${ }^{a}$ Dra $^{\text {a }}$ Regina Célia de Oliveira pela orientação e pelo conhecimento transmitido ao decorrer do projeto; ao Me. Pedro Michelutti Cheliz pelas importantes e indispensáveis contribuições; e à Evelise Diandra da Silva pela amizade e auxílio na elaboração dos mapeamentos.

${ }^{1}$ Cheliz, P. M. Ilha Do Cardoso - Contribuições Para Compartimentação Do Relevo. Dissertação de Mestrado, 2015.

${ }^{2}$ Cunha, C. M. L.; SOUZA, T. A. A Cartografia Do Relevo De Áreas De Sedimentação Recente: O Caso Do Litoral Sul Paulista. São Paulo, UNESP, Geociências, v. 29, n. 2, p. 187-199, 2010.

${ }^{3}$ Petri, S.; Suguio, K. Exemplo de trabalho do mar do litoral sul do Brasil. Not.Geomorfol., Campinas, 1971.

${ }^{4}$ Tessler, M. G..; Suguio, K. Evolução temporal e espacial da desembocadura lagunar de Cananéia-SP. Bolm Inst. oceanogr., São Paulo, 38(1):23-29,1990

5 Tricart, J. Principes et méthodes de la géomorphologie. Paris, Masson, 1965. 